\title{
The Exploratory Study Experience: Developing as a Researcher
}

\author{
Patrícia Alves \\ MSn; MSc; Escola Superior de Enfermagem de Lisboa (ESEL)/ \\ Nursing College of Lisbon; Researcher of \\ Nursing Research \& Development Unit (ESEL) \\ M. Lima-Basto \\ PhD; Escola Superior de Enfermagem de Lisboa (ESEL)/ \\ Nursing College of Lisbon; Researcher of \\ Nursing Research \& Development Unit (ESEL)

\section{Célia Simão Oliveira} \\ PhD, Escola Superior de Enfermagem de Lisboa (ESEL)/ \\ Nursing College of Lisbon; Researcher of \\ Nursing Research \& Development Unit (ESEL)
}

Doi: $10.2478 / \mathrm{mjss}-2018-0033$

\section{Abstract}

This article presents the experience of the researcher during the exploratory study, within the scope of her research in a qualitative paradigm, using the Grounded Theory as a methodological approach, which aims to understand the process of nursing care to the end-of-life patient in the performing activity of living eating and drinking. While structuring the research project, it became important to explore the field of data collection (hospice care unit of a hospital in the Lisbon region) in order to achieve a contact with the reality (represented by the actors), allowing an overview and approximation of the phenomenon under study, the break with the investigator's prentices and the modification of these ideas as well as the construction of the researcher's acceptance by the actors (potential participants), and the decision making during the research course. The sharing of this experience as well as the critical reflections presented here, enabled the researcher to review the difficulties encountered and the strategies used to overcome them, to become aware of the lessons learned and to consolidate them. It is also hoped that the sharing of this experience will help other researchers in their path, allow them to perceive that the mishaps / difficulties of the course they are carrying out are common, that a lot of critical reflection is needed on this trajectory, eventually finding strategies for the problems they might face.

Keywords: exploratory study; end-of-life patient; activity of living eating and drinking; nursing intervention; Grounded Theory

\section{Introduction}

The researcher's critical reflection on her research processes allows to (re) look at her experience, the consolidation of learning and development as researchers. It is also considered that sharing experiences among researchers is an important aspect, particularly for those who are starting the process. Thus, it makes sense to elaborate an article that mirrors the beginning of this researcher's path, that is, the exploratory study carried out in the scope of the research developed during the 
PhD course in Nursing entitled "Process of nursing care to the end-of-life patient ${ }^{1}$ performing activity of living $(A L)^{2}$ eating and drinking". Thus, the design of this research will be presented in a summarized way, so as to frame the development of the exploratory study, it's importance in the field of qualitative research using the Grounded Theory method and a critical reflection on this path, and finaly the difficulties the researcher came across, as well as the strategies used to overcome them and the lessons learned.

\section{Investigate the "Process of Nursing Care to the End-of-Life Patient Performing AL Eating and Drinking"}

From the reflection on the researcher's accumulated experience, from the discussion with peers and teachers, the bibliographical research and systematic review of the literature that has been elaborated, the scope of this study arises, whose research question is: "What is the process of nursing care to the end-of-life patient performing the activity of living eating and drinking?". With this research it is intended to understand the process of nursing care to the end-of-life patient in the performance of $A L$ eating and drinking, describing the main factors that influence this process, identifieng tnursing interventions and coresponding results.

Because the main purpose was to obtain knowledge about the process of nursing care that occurs between the nurse and the end-of-life patient and this is a social phenomenon of interactive nature, a symbolic interactionism was chosen, as a guiding perspective and for the Grounded Theory as a methodological approach, since this methodology allows the construction of a theory through the analysis of data (Charmaz, 2014) and is used to explore social processes in human interactions.. It also allows to describe and find complete theoretical explanations of the phenomenons in natural environments or when necessary, to explore substantive areas, about which very little was known or about which is necessary to obtain a new understanding (Streubert \& Carpenter, 2002; Strauss \& Corbin 2008). In this methodological approach we start with a study area and the theory emerges from the data and, once it is based on the data, it is more possible that it can generate knowledge, offering a better understanding of the phenomenon and providing a meaningful guide to the action (Strauss \& Corbin, 2008).

It was decided to perform the data collection in a palliative care unit of a Portuguese hospital. These units refer to services specifically designed to treat and care for the patient in a palliative situation (Capelas \& Coelho, 2014) (including the end-of-life patient), where professionals with training in palliative care work and follow this philosofy of care. It is therefore expected to find best practice nursing care to end-of-life patients, that are important to understand.

The data collection techniques used in this research was the participant observation of care, from interactions between the different participants (nurse / patient / family), semi-structured interviews with nurses and documentary research (nursing records). The study participants are nurses of the unit, who care for end-of-life patients that agreed to participate in this research; endof-life patients beeing cared for by these nurses, aware and willing to participate in the study; family

\footnotetext{
${ }^{1}$ Although it is difficult to agree on the definition of end-of-life patient (Alves \& Neves, 2016) (also referred to in the literature as terminally ill, terminal patient), since there are differences in their meaning among patients, caregivers and health professionals (Ferreira et al, 2012), the concept of the end-of-life patient was adopted as someone who has a chronic illness and no possibility of cure, with worsening symptoms, whose death is expected to close and receives palliative treatment (Pacheco, 2004). The Sociedad Española de Cuidados Paliativos (SECPAL) (2014) adds that this patient and family suffers from great emotional impact related to the proximity of death and the life prognosis is less than six months, which is also defended by Neto (2006) when he states that this patient has, on average, an over-life of three to six months.

${ }^{2}$ Activities of living refer to all the activities we carry out, which are an integral part of life, which together contribute to the complex process of life and are influenced by biological, psychological, sociocultural, environmental and political. The AL eating and drinking plays a significant role in the standard of living of all people, being essential to it, since human life can not be maintained for a long time if the person does not feed, survival and growth. There are many dimensions in this AL beyond the physical intake of food and liquids intellectual and emotional diversity; sociocultural diversity; access to food and drink, and sociocultural factors influence the way food and beverages are selected, as well as the way meals are eaten (Roper, Logan \& Tierney, 1995).
} 
/ significant persons of patients, that also agreed to participate in the study.

\section{The Exploratory Study Experience}

After the authorization has been granted by the hospital institution to carry out the data collection, since the investigator must, first of all, request authorization to conduct collection of data at the establishment under research (Fortin, 2006), the first step was preparing access to the site in the palliative care unit, where the investigation is currently ongoing. As the access to the site is an important aspect to carry out the research, negotiated with the entities present on site (Camalhão \& Camalhão, 2014), initially a meeting with the Nurse Director and The Clinical Directorate has been carried out, beeing presented the research project (that was very welcomed) and discussed the best way to access the site for conducting the exploratory study. Relevant information of the institution was also shared with the researcher.

Even though access to the site was planned, as the researcher got more and more engaged with the team, patients, and service dynamics, planning improvements have been implemented. It was our intention to explore the field in order to ensure quality of information (Quivy \& Campenhoudt, 2005), to know more about the phenomenon under study (Gil, 1994) in order to reveal a light on certain aspects of the studied phenomenon, in which the researcher would not have spontaneously thought for himself, and thus completing the working tracks breaking with possible prejudices from the researcher (Quivy \& Campenhoudt, 2005). In Grounded Theory this aspect is essential because the investigator can not start an investigation with preconceived concepts. The need for an objective posture is critical, beeing open and listen to what others have to say, see what others do and represent this as accurately as possible, allowing new interpretations of the phenomenon under study (Strauss \& Corbin, 2008).

Given that in Grounded Theory we try to find out what occurs in the research environments in which we are integrated and how is life of our research participants (Charmaz, 2009), the exploratory study also intends this Integration, the construction of a relation that promotes the acceptance of the presence of the researcher in the context, the contact with the reality lived by the actors (Quivy \& Campenhoudt, 2005) and the knowledge of the privileged informants / key. It was also the researcher's intention to understand if the data collection techniques she intended to use were adequate, how best to operationalize them, identify their difficulties during the use of the data and make decisions about the research course.

When she came to the context, the researcher met with the nurse responsible for the palliative care unit, to present the project, since it is important to make preliminary contacts with key people at the selected location, ensuring cooperation and access to informants (ie the researcher needs to obtain permission to enter the scenario) (Pollit, Beck \& Hungler, 2004). The nurse presented the unit to the researcher, talking about: the organization of the service; the organization of the nursing team and the articulation with other multidisciplinary teams; the experience of the elements of the nursing team; the distribution of nursing work and its connection with the direct provision of care; the care specificities of inpatients in the service, helping in the choice of end-of-life patients that could be part of the study. This participant would be an important element in this journey, not only because of the privileged information/key, but because it is someone the researcher can ask for clarification when there are doubts about specific occurrences, since she has a deep knowledge of the service, of all patients and nurses.

During the exploratory study, the researcher consulted patients' clinical processes to learn about the situation of people, and doubts about the inclusion criteria used for the sick participants, "end-of-life patients", were emerging. The questions that came at the time were: "How to know that a patient is at the end of life? Who defines this? Is it defined? Where is this clinical decision documented? "To solve this questions, the key element of the service - the responsible nurse, was of upmost importance - clarifying that these situations are usually discussed in a team, with family and patient, and in those cases, the condition is recorded in the patient's clinical process. Thus, it made sense to select for patient-participants those who had been identified in the clinical process as end-of-life patients.

Initially, the researcher also participated in some of the multiprofessional team meetings, 
where she had the opportunity to become better acquainted with patients, their life path and healthillness, also allowed her to meet some elements of the team and their dynamics promoting a better accepance of her presence as a researcher, that is, building familiarity. This is an essential aspect of this study because to understand the phenomenon, the researcher must be integrated into the environment (Spradley, 1980). In these moments when the researcher went to the field, in addition to getting acquainted with some of the elements of the team, the way the service and the team work, also allowed her to perceive which participants (nurses) would be key informants.

Working on the premise that for participant observation, one has to become familiar with the context and with the actors (potential participants) and also being accepted by them (Spradley, 1980; Quivy \& Campenhoudt, 2005), during her presence in the field, she talked with nurses who were on duty explaining her role and making available a document with relevant information about the research. In fact, the researcher must at the beginning ensure an explanation of the reasons for her presence, the nature of the work to be carried out and what she will do with the results (Trad. Quivy \& Campenhoudt, 2005).

When she started the participant observation, the researcher realized that some nurses were initially not comfortable by the observation of their practices, but following several conversations to explain the work she was carrying out and the methodology, they started to welcome her presence. She also talked with the operational assistants because, although these professionals were not participants in the research, they had to be informed about her presence (initially she was unfamiliar to the service) so that gradually all team members would become aware of her presence. The same happened with other professionals that from time to time went to the service. In this case, there is a question of respect for professionals of the unit because it is necessary to understand that the way the researcher will be accepted is directly related to the way in which she accepts and respects her interlocutors for what they are, avoiding to judge them or behaving with indiscretion (Quivy \& Campenhoudt, 2005).

These gradual contacts with the context, professionals and patients were critical for constructing the identity of the researcher as such, thus mirroring the participants themselves and demarcating their role. The fact that the participants feel more familiar with the presence of the researcher, promotes their involvment in the study, obtaining a better understanding of their lives and interactions in that context (Morse, 1991).

Interestingly, in regards with patients and families, the researcher felt acceptance from the start, not being present when patients in care were physically exposed, where they could feel less comfortable, as is the case with hygiene care. The researcher was in observation all the times when aspects of "eating and drinking" would emerge, but also in other times of care with low exposure from the patient, so that the nurse and the patient would feel more comfortable with her presence, also contributing for the researcher to be more adapted to the context.

Before the researcher went to the field, she prepared two documents about the study for the participants (one for the nurse and another for patients/families). The need for two diferent documents was related to the fact that a clear and simpler language regarding the research was important to ensure better understanding for patients/families. The other document was the informed consent term for the research participants.

Prior to the field research, the researcher developed an observation guide (Table 1), to ensure clear guidance for the implementation of the participant observation in the field. Initially, the researcher experienced challenges in drawing up the observation guide, because although she needed something that would "direct" her eye, because she was afraid of getting lost "looking at everything and at the same time covering very little", she had little knowledge of the service and had uncertainties about what to ensure in the guide. Therefore, the researcher developed the observation guide based on the research question, the objectives of the study, the readings she made on the techniques for data collection (namely the author James Spradley) and the literature that she had consulted for elaborating the problem of the project, because Strauss \& Corbin (2008) state that before beginning a project, the researcher can consult the literature to formulate questions that act as a starting point during observations and initial interviews. She then discussed the aspects to be included in the guide with her guiding teachers, and took into account the initial meeting she had with the Head of the institution. The guide was elaborated with the concern of 
being a guide for the observation, but being flexible enough at the same time, so that the researcher didn't had to focus only on the information present in the guide, ensuring that she would be aware to everything that surrounds her and relevant for the research, even if it was not included in the guide. Effectively, studying the already mentioned process, which is a social phenomenon and therefore of an interactive nature, and using Grounded Theory as a methodological approach, in which theory emerges from the data (Strauss \& Corbin, 2008), it is necessay to ensure an open mind and to pay attention to all events and interactions that may arise (and some are unexpected), so that the understanding of the researcher is supported. Looking back to the several aspects included in the guide for observation, they reflect a duality (their existence appeared normal in the initial stage), leading to the conclusion that the guide has very general aspects that refer to what Spradley (1980) mentions as "descriptive observation", which in the beginning helps to understand the complexity of the field (such as" the knowledge of the service, how it works ...") so that afterwards more focused aspects can be observed (such as" where people eat "," reaction of the patient to the nurse's intervention"). The guide has been reviewed throughout the exploratory study.

Table 1: Observation Guide

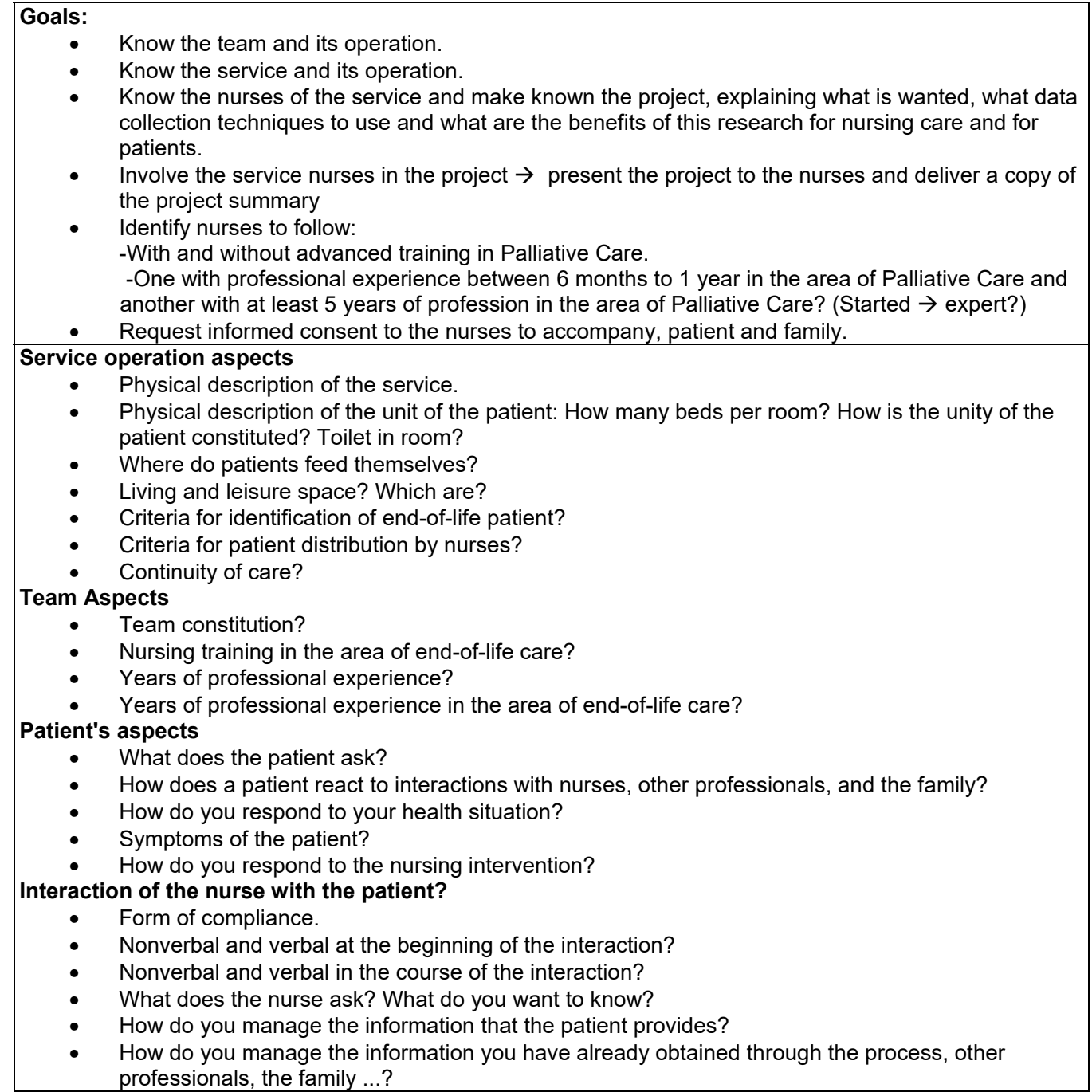




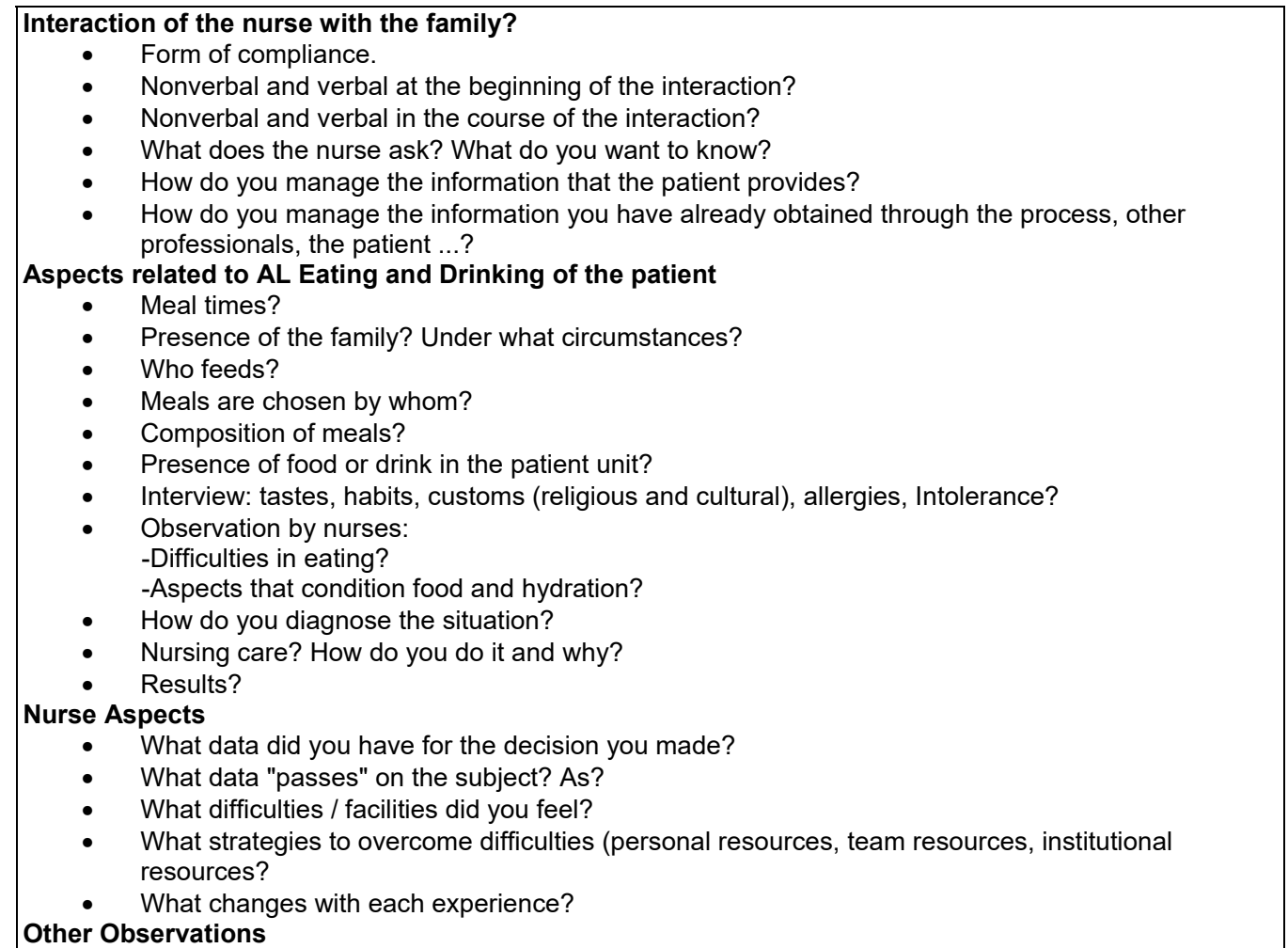

To make the participant observation, the researcher had to decide who to observe. Initially she had doubts about nurses whose care practices she should observe, but based on the research question, the conversations with the context actors and under reflection, the researcher realized that she had first to choose one or two patients that met the criteria for beeing participants of the study, so that she could see afterwards the nursing care given to them, provided that this observation had been consented by the patient / family and by the nurse. Therefore, there was an intention in the selection of the participants and the care to be observed, which is recommended by the method used, remembering that in the open coding ${ }^{3}$ of the Grounded, Theory Strauss \& Corbin (2008) it states that sampling is open to all people, places, situations that guarantee greater opportunities for discovery.

Concomitantly with the relationships the researcher had established with nurses, she also established relationships with patients and families. Thus, even in the absence of the nurse, the researcher talked to the patients/families in order to get to know them better, to build a relationship and an open relation between them. After the interventions of the nurses, the researcher often talked with patient/family in order to understand how they felt and what the consequences of the nursing action/interaction. The interactions with some patients were a great challenge for the researcher, since there were situations of people who had already lost or were losing their ability to talk and write, due to the stage of their disease, and in this cases non verbal communication was used. The researcher realized that this aspect would be overcome by her continuous knowledge of the patients, the relationship she was establishing with them but also by paying attention to the details they gave her. In this cases, nurses explained to the researcher the meaning of some specific signs from individual patients, allowing her to overcome these barriers of communication

\footnotetext{
${ }^{3}$ In the Grounded Theory method, open coding is the initial analytical process whereby concepts are identified and their properties and dimensions are discovered in the data (Strauss \& Corbin, 2008).
} 
and managing her collect data from these patients.

Another challenging aspect that occurred during the exploratory study was related to the moments in which the patient or nurse asked the researcher for something, confronting her with the dilemma of "as far as she could and/or should or should not participate." There were situations where the researcher was a moderate participant (Spradley, 1980) since she participated from time to time, when requested by the patient or nurse, in events that did not interfere with the phenomenon under study. Some of these experiences, which occurred during the exploratory study, allowed her to reflect and raise awareness about the most appropriate level of participation, so as not to create expectations for the participants during data collection, not to interfere with the phenomenon under study and to maintain a balance between objectivity ${ }^{4}$ and sensitivity ${ }^{5}$ (Strauss \& Corbin, 2008).

After the initial moments of participant observation during the exploratory study, field notes were recorded of the observed episodes. From the critical reflection of the notes made and the comments / suggestions of the guiding teachers from the recorded registers, it was possible for the researcher to realize her difficulties in observing, what she did not registered and what was relevant in this journey, such as: body language Interaction; the researcher feelings; some interpretations that emerged throughout the day-to-day observation of nurses and patients, their speeches and practices. The researcher also began to analyze the data, in order to practice the techniques mentioned by Strauss \& Corbin, in order to feel more comfortable later in this process (Strauss \& Corbin, 2008). All this was an important learning for subsequent observations and data analysis. The researcher also interviewed a privileged informant, which helped her finding her dificulties during the interview allowing her to rethink new strategies to overcome them. This journey allowed the researcher to find new information for the research.

\section{Conclusion}

This exploratory study journey was important for the researcher to familiarize herself with the context and phenomenon under study, to construct her identity as a researcher and to demarcate her position. It made possible to get to know the team, the service and its way of working, as well as patients and families, where her presence gradually became more familiar in the context of data collection. It was also important for the researcher to assess the participant inclusion criteria, to make decisions about the field research process and to improve participant observation, the field notes and interviews she conducted, and to practice data analysis. In short, it can be said that this journey allowed the researcher to "open horizons", at the level of her acceptance for data collection and at the level of her development as a researcher.

\section{References}

Alves, P. \& Neves, S. (2016). Quando se cuida em fim de vida: a pessoa como centralidade do cuidado. In Rebelo, T. et al (Eds.). Quando o silêncio se faz fala: a escuta na aprendizagem do cuidado de enfermagem (pp. 261-274). Loures: Lusodidata.

Camalhão, M.I \& Camalhão, S. (2014). Grounded Theory: adaptações ao contexto da deficiência e adaptação. Indagatio Didactica, vol. 6(3), outubro, 140-155.

Capelas, M. \& Coelho, S. (2014). Pensar a organização de serviços de cuidados paliativos. Revista Cuidados Paliativos, Vol 1, $\mathrm{n}^{\circ} 1$, março, 17-26.

Charmaz, K. (2009). A construção da teoria fundamentada: guia prático para análise qualitativa. Porto Alegre: Artmed.

Charmaz, K. (2014). Constructing grounded theory $\left(2^{\text {nd }}\right.$ end). Los Angeles: Sage.

Fortin, M.F (2006) O processo de investigação. Loures: Lusociência.

\footnotetext{
${ }^{4}$ Objectivity means the ability to reach a certain degree of distance from research materials and to represent them fairly; the ability to listen to the informants' words and give them a voice independent of the researcher's voice. Objectivity is necessary to arrive at an unbiased and accurate interpretation of the facts (Strauss \& Corbin, 2008)

${ }^{5}$ Sensitivity is the ability of the researcher to perceive the subtle nuances and meanings of the data and to recognize the connections between concepts (Strauss \& Corbin 2008).
} 
Ferreira, P.; Antunes, B.; Pinto, A. \& Gomes, B. (2012). Cuidados de fim de vida: Portugal no projeto europeu PRISMA. Revista Portuguesa de Saúde Pública, 30 (1), 62-70.

Gil, A. (1994). Métodos e técnicas de pesquisa social. (4a edição). São Paulo: Atlas.

Morse, J. (1991). Subjects, respondents, informants and participants? Qualitative Health Research, 1 (4), p. 403-406.

Morse, J. (1994). Designing funded qualitative research. In Denzin, N.; Lincoln, Y. (Eds). Handbook of qualitative research. London: Sage.

Neto, I. (2006). Princípios e Filosofia dos Cuidados Paliativos. (cap. 1). In Barbosa, A. \& Neto, I (Editores). Manual de Cuidados Paliativos. Lisboa: Centro de Bioética - Faculdade de Medicina de Lisboa.

Pacheco, S. (2004). Cuidar a Pessoa em Fase Terminal - perspectiva ética. $2^{a}$ Edição. Loures: Lusociência

Pollit, D.; Beck, C. \& Hungler, B. (2004). Fundamentos de pesquisa em enfermagem: métodos, avaliação e utilização. (5 $5^{a}$ edição). São Paulo: Artmed Editora S.A.

Quivy, R. \& Campenhoudt, L.V. (2005). Manual de Investigação em Ciências Sociais. (4ª edição). Lisboa: Gradiva.

Roper, N.; Logan, W. \& Tierney, A. (1995). Modelo de Enfermagem. $3^{a}$ edição. Alfragide: Editora McGraw-Hill de Portugal

Roper, N.; Logan, W. \& Tierney, A. (2001). O modelo de enfermagem Roper-Logan-Tierney. $1^{\text {a }}$ edição. Lisboa: Climepsi Editores.

Sociedad Española de Cuidados Paliativos (2014). Guia de Cuidados Paliativos. [Online] Available http://www.secpal.com/biblioteca_guia-cuidados-paliativos_2-definicion-de-enfermedad-terminal (January 30, 2017).

Spradley, J. P. (1980). Participant observation. New York: Holt, Rinehart and Winston

Strauss A. \& Corbin, J. (2008). Pesquisa Qualitativa - técnicas e procedimentos para o desenvolvimento de teoria fundamentada. $2^{\mathrm{a}}$ edição. Porto Alegre: Artmed.

Streubert, H. \& Carpenter, D. (2002). Investigação qualitativa em enfermagem - avançando o imperativo humanista. Loures: Lusociência. 